\title{
Anatomical Study of Racosperma (ex-Acacia) mangium Tissues Cultured In Vitro
}

\author{
N. K. Takemori ${ }^{1}$, R. Marschner ${ }^{1}$, M. Quoirin ${ }^{1 *}$, C. Bona ${ }^{1}$ and F. Zanette ${ }^{2}$. \\ ${ }^{1}$ Departamento de Botânica, ${ }^{2}$ Departamento de Fitotecnia, Universidade Federal do Paraná, C.P. 19031, Curitiba, \\ PR, Brazil
}

\begin{abstract}
In order to achieve adventitious shoot regeneration from young tissues of Racosperma mangium, several combinations of growth regulators were tested. Kinetin (KIN) and $\alpha$-naphthalenacetic acid (NAA), thidiazuron (TDZ) and NAA or indole-3-butyric acid (IBA), 4-CPPU and 2,4-dichlorophenoxyacetic acid (2,4-D) were added to basic medium composed of MS salts, MS vitamins and 3\% sucrose. Sections of hypocotyls and cotyledons of young seedlings were cultivated on these media. Calli developed on different media and, after two to three months, some of them regenerated organized structures. Histological studies revealed hypertrophy and hyperplasy of medular and cortical parenchyma cells of hypocotyl and cotyledon parenchyma. Formation of meristematic cells and traqueary elements from parenchyma was observed during in vitro culture. In some cases, nodules of traqueary elements were formed. The highest differentiation into meristematic cells was found in cotyledon tissues cultured on 4-CPPU (8.07 $\mu M)$ and 2,4-D (1.13 $\mu M)$.
\end{abstract}

Key words: 4-CPPU, Leguminosae, TDZ, Tissue culture

\section{INTRODUCTION}

Racosperma (ex- Acacia) mangium (Leguminosae family) is used in tropical regions to protect and restore soils damaged by intensive cultivation or deforestation. This property is largely due to the symbiotic association that this species develop with the nitrogen-fixing bacteria Rhizobium (Brewbaker, 1989). The timber is suitable for particle board, veneer and paper pulp (Nat. Res. Council, 1983).

A protocol to regenerate shoots from in vitro cultured tissues is important for future programs of genetic transformation of this species. In the case of Acacia genus, eight species, A. senegal, A. albida, A. nilotica, A. koa, A. liguta, A. mangium, A. auriculiformis and A. salicina, have shown some regeneration response when grown in vitro (for a review, see Quoirin et al., 1998). For A. mangium, Kitani and Yasutani (1997) described the formation of adventitious shoots on cotyledons cultured on MS medium supplemented with an auxin (2,4-D, NAA or 4Cl-IAA) and TDZ.
In order to understand the differentiation of tissues of $R$. mangium during the in vitro culture in the presence of growth regulators combinations, sections were prepared, their anatomy was observed under microscope and compared with sections of in natura organs.

\section{MATERIAL AND METHODS}

Plant material: Seeds of Racosperma mangium, obtained from the Australian Tree Seed Centre (CSIRO, Australia), were scarified for one minute in boiling water. After scarification, the seeds were surface sterilized in $2.5 \%(\mathrm{v} / \mathrm{v})$ sodium hypochlorite solution and then rinsed three to four times in sterile water. The seeds were germinated in vitro on cotton embebded with half-strength MS (Murashige \& Skoog, 1962) mineral solution. Five millimeter long sections of hypocotyls and entire cotyledons from four weeks plantlets were used for the experiments. 
Culture media and tissue culture: The basic medium consisted of MS salts, MS vitamins, $30 \mathrm{~g} / \mathrm{L}$ sucrose and $7.5 \mathrm{~g} / \mathrm{L}$ agar Sigma Cat. $\mathrm{N}^{\circ}$ 7921. Several combinations of growth regulators were tested, including NAA and TDZ, 2,4-D and 4-CPPU, NAA and KIN (Table 1). The pH of media was adjusted to 5.8 before autoclaving at $120^{\circ} \mathrm{C}$ for $20 \mathrm{~min}$. For each treatment, 32 explants were used. Every experiment was repeated at least three times.

The cultures were incubated in a culture room under fluorescent day light tubes, giving a photon flux density of 40 to $50 \mu$ mol.m ${ }^{-2} . \mathrm{s}^{-1}$; the temperature was $26 \pm 3^{\circ} \mathrm{C}$ and the photoperiod of $16 \mathrm{~h}$.

Table 1. Combinations of growth regulators tested for A. mangium cotyledon and hypocotyl cultures.

\begin{tabular}{c|cccccccccc}
\hline Growth regulators & \multicolumn{110}{c}{ Concentrations $(\mu \mathrm{M})$} \\
\hline NAA & 0 & 0 & 0 & 0 & 2.7 & 2.7 & 2.7 & 2.7 & 2.7 & \\
KIN & 1.4 & 2.3 & 4.6 & 9.3 & 0 & 1.4 & 2.3 & 4.6 & 9.3 & \\
NAA & 2.7 & 2.7 & 2.7 & 2.7 & 5.4 & 5.4 & 5.4 & 5.4 & & \\
TDZ & 0 & 0.4 & 0.9 & 1.8 & 0.4 & 0.9 & 1.8 & 15.0 & & \\
IBA & 0.5 & 0.5 & 0.5 & 0.5 & 2.5 & 2.5 & 2.5 & 2.5 & & \\
TDZ & 0.9 & 1.8 & 2.7 & 4.5 & 0.9 & 1.8 & 2.7 & 4.5 & & \\
2,4-D & 0 & 1.1 & 2.2 & 4.5 & 5.6 & 0 & 1.1 & 2.2 & 4.5 & 5.6 \\
4-CPPU & 8.1 & 8.1 & 8.1 & 8.1 & 8.1 & 20.2 & 20.2 & 20.2 & 20.2 & 20.2 \\
\hline
\end{tabular}

Abbreviations: 4-Cl-IAA, 4-chloroindole-3-acetic acid; 4-CPPU, N-(chloro-4-pyridil)-N'-fenylurea; 2,4-D, 2,4dichlorophenoxyacetic acid; IBA, indole-3-butyric acid; KIN, kinetin; NAA, $\alpha$-naphthaleneacetic acid; TDZthidiazuron, 1-phenyl-3-(1,2,3-thidiazol-5-yl)urea; BA, $\mathrm{N}^{6}$-benzyladenine.

Histological studies: Fresh hypocotyls and cotyledons were cut from one month plantlets and used for histological studies, in comparison with callus forming explants, 60 and 120 days after inoculation on culture media.

For semi-permanent slides, the explants and calli were fixed in FAA $70 \%$ for $48 \mathrm{~h}$ (Johansen, 1940). The sections were cleaned in sodium hypochlorite $20 \%$, stained with basic fuchsin and astra blue (Roeser, 1962). The slides were mounted in glycerinated gelatin (Berlyn and Miksche, 1976).

For permanent material, the tissues were fixed by the same technique and dehydrated in ethanol. They were embedded in glycol methacrylate (GMA) following the procedure of Feder and O'Brien (1968). Sections 5-7 $\mu \mathrm{m}$ thick were cut with a rotative microtome, stained with toluidin blue (O'Brien et al., 1964) and mounted in Entelan.

\section{RESULTS}

\section{In natura hypocotyl and cotyledon organization}

Hypocotyl transversal sections showed a monolayer epidermis. Below this appeared a layer of parenchyma cells, followed by a densely coloured strip, probably constituted by colapsed cell walls, and cortical parenchyma.

Central cylinder was formed by four vascular bundles protected by schlerenchyma in the external region of the phloem. The pith was composed by fundamental parenchyma (Fig. 1). Traqueary elements were long with annealed thickenings in protoxylem region and helicoidal pittered thickenings in the metaxylem zone (Fig. 2). 

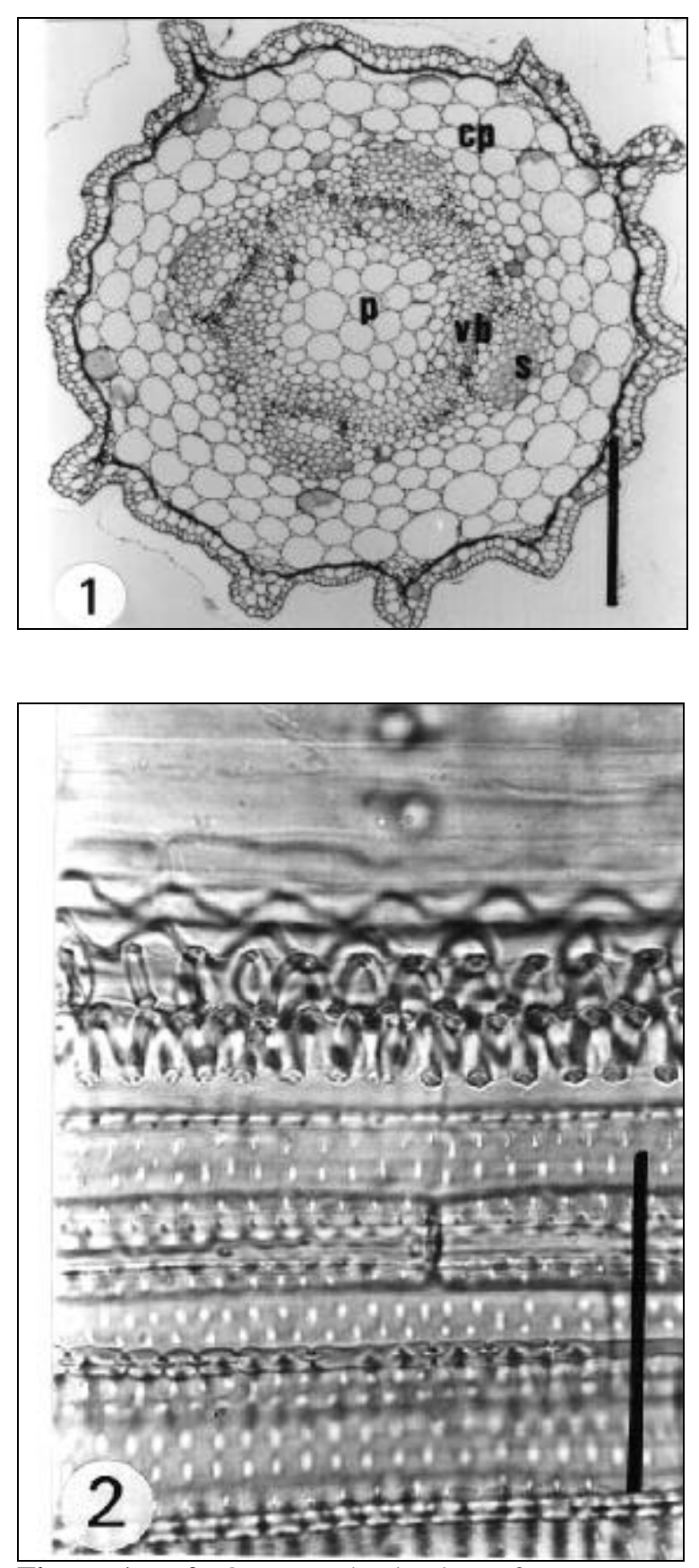

Figure 1 to 2. One month plantlets of Racosperma mangium. Figure 1. Cross section of hypocotyl (Bar $=200 \mu \mathrm{m}$ ). Figure 2. Tracheids of hypocotyl (Bar= $40 \mu \mathrm{m}$ ). Legend: (cp) cortical parenchyma; (vb) vascular bundle; (s) schlerenchyma; (p) pith;

The cotyledon presented a uniseriate epidermis with a great quantity of stomates at the adaxial side. Two layers of palisade parenchyma were observed inside the cotyledon. Chlorophyllic parenchyma of abaxial side was formed by isodiametric cells with small intercellular spaces. Between this parenchyma and the abaxial epidermis, appeared a strip of dense material, as was observed in the hypocotyl section. Vascular bundles were disposed in the middle region of the cotyledon, between palisade and regular parenchyma (Fig. 3). Tracheids were elongated with helicoidal thickenings (Fig. 4).
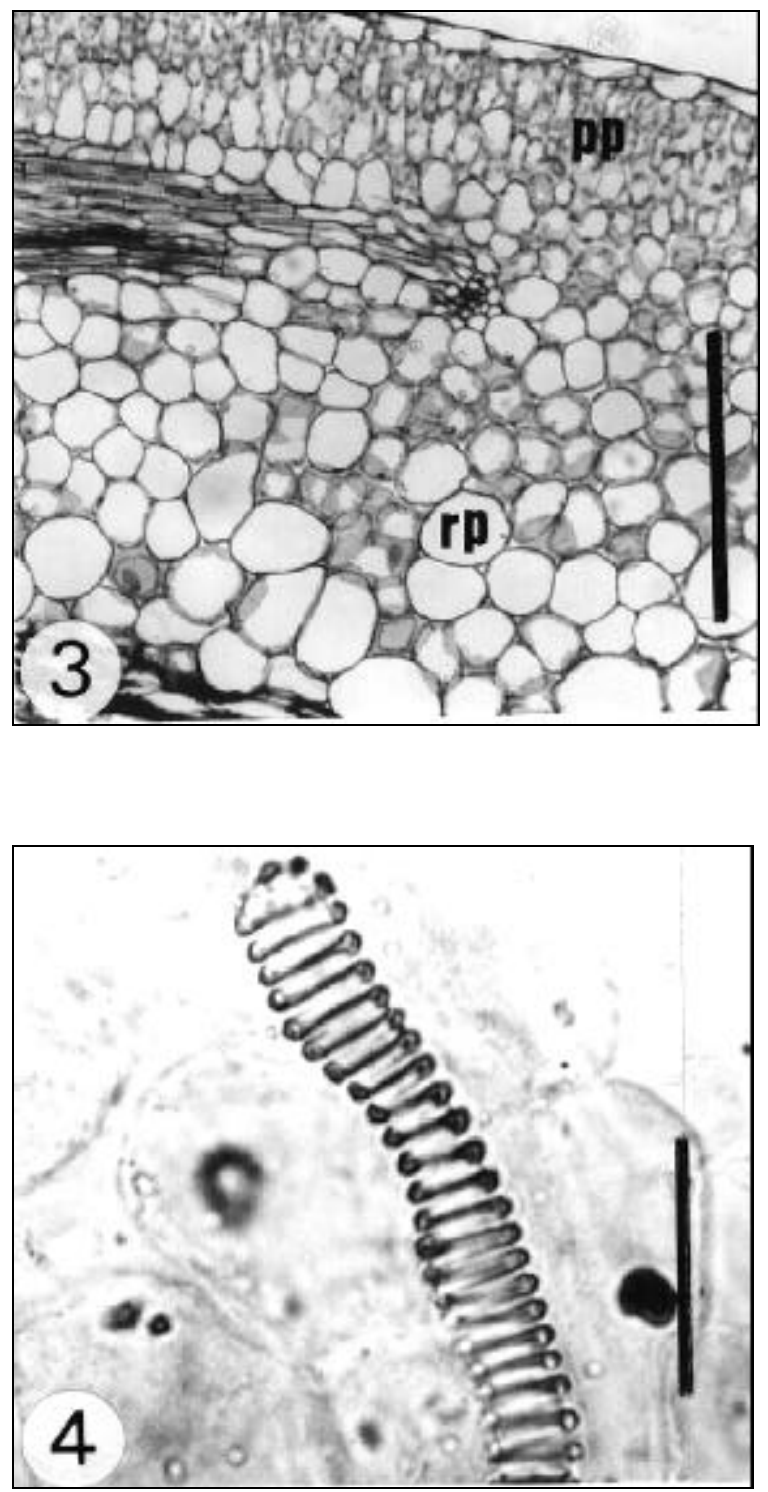

One month plantlets of Racosperma mangium. Figure 3. Cross section of cotyledon (Bar $=20 \mu \mathrm{m}$ ). Figure 4. Tracheid of cotyledon (Bar $=20 \mu \mathrm{m})$. Legend: (pp) palisade parenchyma; (rp) regular parenchyma. 


\section{Effect of kinetin and naphthaleneacetic acid on hypocotyl and cotyledon explants}

Callus were initiated at the cut ends of explants and then spread all over the explant surface. After 45 days, callogenesis was observed in control and in treated explants as well. The percentages of callus formation varied between 55 and $100 \%$ for cotyledons and 86 to $100 \%$ for hypocotyl explants. These calli did not differentiate buds nor roots.

Histological studies showed the proliferation of cells from cortical and medular parenchyma and the formation of new tracheary elements near the xylem (Fig. 6 and 7) when hypocotyls were cultivated in the presence of NAA $(2.7 \mu \mathrm{M})$ and KIN $(2.3 \mu \mathrm{M})$ during 100 days.

\section{Effect of thidiazuron and naphthaleneacetic acid on hypocotyl and cotyledon explants}

Callus proliferation was observed on hypocotyl explants for all combinations of TDZ/NAA tested. The rate of proliferating hypocotyls varied between 68.75 and $100 \%$. When cotyledons were used, callogenesis appeared in $21.8 \%$ of control explants and 56.25 to $100 \%$ of the explants grown in the presence of growth regulators. After 10 to 12 weeks on the same medium, caulinar meristems were observed on cotyledon calli (Table 2). Later on, they developed into buds (Fig. 5). Calli derived from hypocotyl did not regenerate buds.

Anatomical studies revealed the presence of nodules formed by xylem cells inside $\mu \mathrm{M}$ of TDZ . Tracheids were short and wide; they were organized in nodules surrounded by cells with parenchyma characteristics probably phloem cells (Fig. 7 and 9). Meristemoid structures were also observed in the calli grown in the presence of $2.7 \mathrm{M}$ of NAA and $0.34 \mathrm{M}$ of TDZ (Fig. 10).

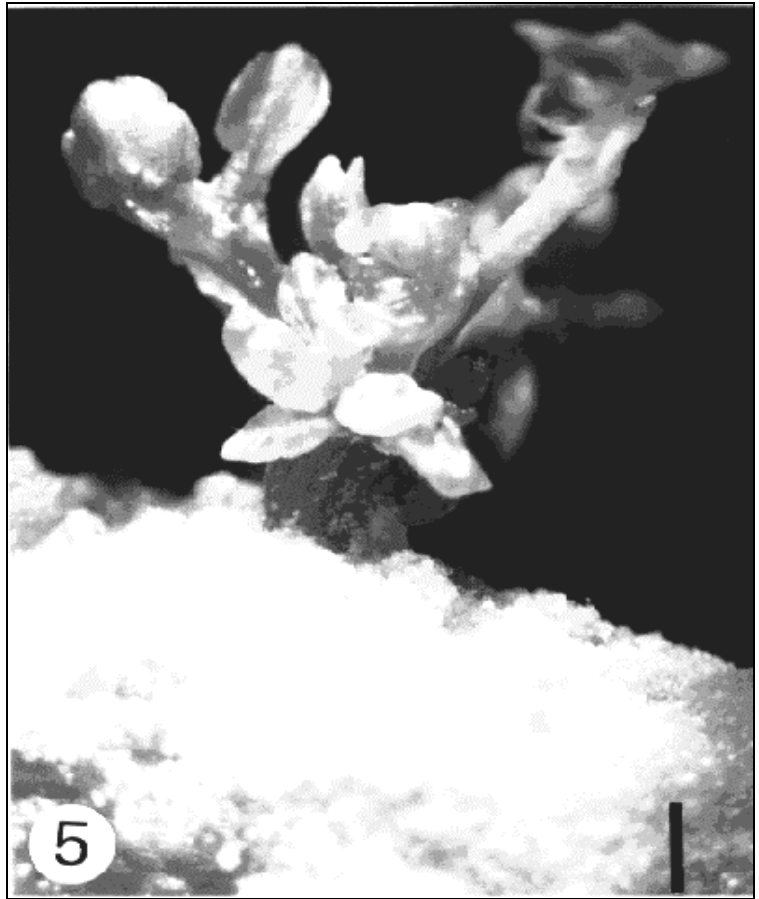

Figure 5. Bud developed on callus of cotyledon on NAA $(0.91 \mu \mathrm{M})$ and TDZ $(5.4 \mu \mathrm{M})(\mathrm{Bar}=1 \mathrm{~cm})$.

Table 2. Effect of combinations of TDZ and NAA on the organogenesis of calli from Racosperma mangium hypocotyls.

\begin{tabular}{|cc|c|}
\hline $\begin{array}{c}\text { Growth regulators } \\
(\mu \mathrm{M})\end{array}$ & $\begin{array}{c}\text { Callus developing } \\
\text { caulinar meristem } \\
(\%)^{*}\end{array}$ \\
\hline TDZ & NAA & 0 \\
\hline 0 & 0 & 0 \\
0 & 2.7 & 0 \\
0.4 & 2.7 & 3.57 \\
0.4 & 5.4 & 0 \\
0.9 & 2.7 & 13.54 \\
0.9 & 5.4 & 5.68 \\
1.8 & 2.7 & 5.13 \\
1.8 & 5.4 & \\
\hline
\end{tabular}

* Mean of three experiments observed after 12 weeks.

Effect of thidiazuron and indole-3-butyric acid on hypocotyl and cotyledon explants

Similarly to what was observed when TDZ was combined with NAA, explants maintained on media containing TDZ and IBA formed calli and, after three months, caulinar meristem appeared in few cases (4 to $6 \%$ of explants on $0.5 \mathrm{M}$ of IBA and 0.9 to $2.7 \mathrm{M}$ of TDZ). 


\section{Effect of 2,4-D and 4-CPPU on hypocotyl and cotyledon explants}

After two months, cotyledons and hypocotyl explants developed calli in the presence of all the combinations of 2,4-D and 4-CPPU. Nodules appeared on calli maintained for two to three months on media containing 1.1 or $2.2 \mu \mathrm{M}$ of $2,4-\mathrm{D}$ and $8.1 \mu \mathrm{M}$ of 4-CPPU, or $20.2 \mu \mathrm{M}$ of 4CPPU without 2,4-D. Histological studies of 60 days explants showed that cellular differentiation occurred in parenchyma cells. Three types of cells developped: meristematic (small cells with dense nucleus and cytoplasm, and weakly thickened walls) (Fig. 11-12), tracheid elements with secondary thickening (Fig. 14 and 15) and parenchyma cells (Fig. 16). Meristematic cells were found near the epidermis. In some cases, the meristem grew outwardly through the epidermis, though there was no differentiation into organs (Fig.11 and 13). When calli were maintained for 60 days on medium containing $20.2 \mu \mathrm{M}$ of 4 -CPPU, nodules of xylem cells were formed (Fig. 16 and 17) as in the case of TDZ and NAA treatment.
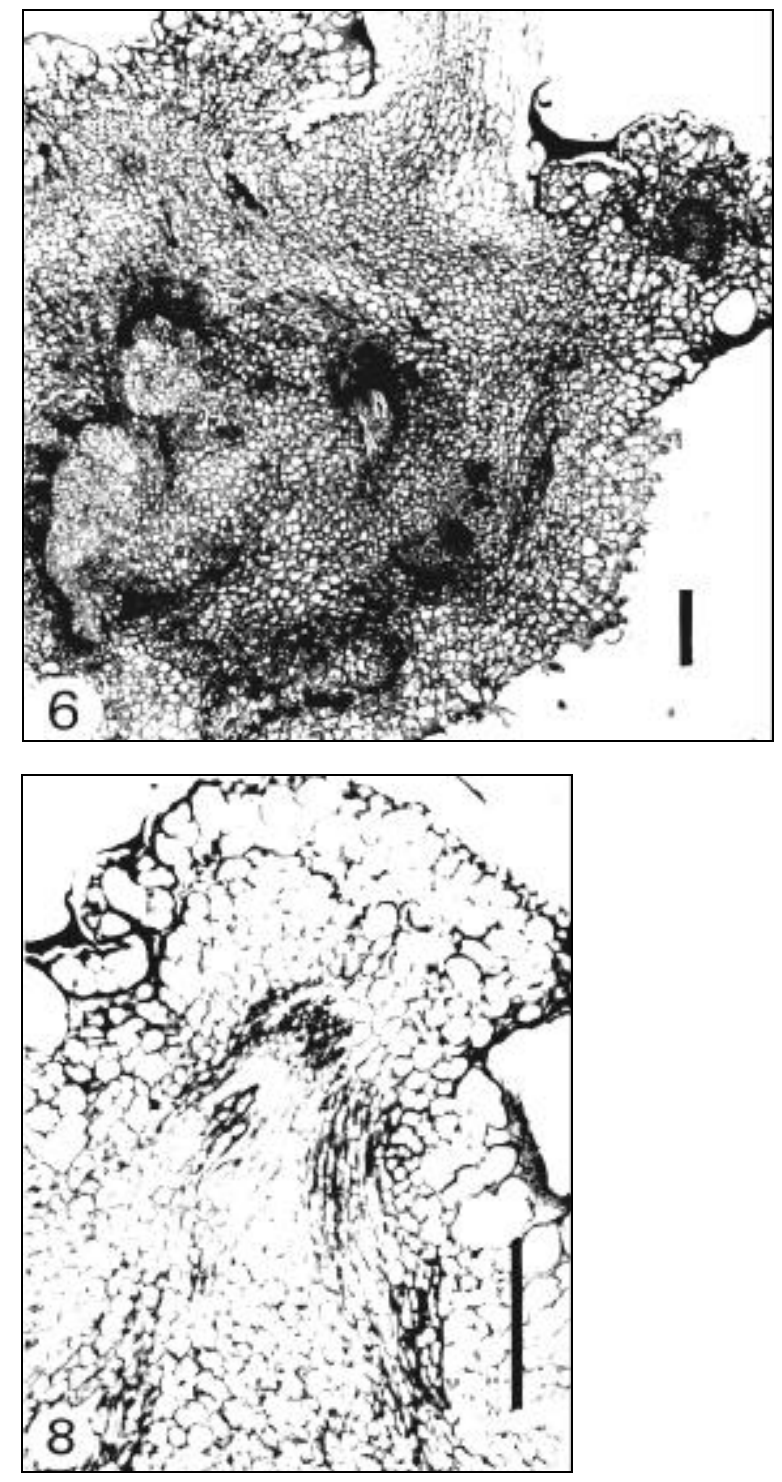
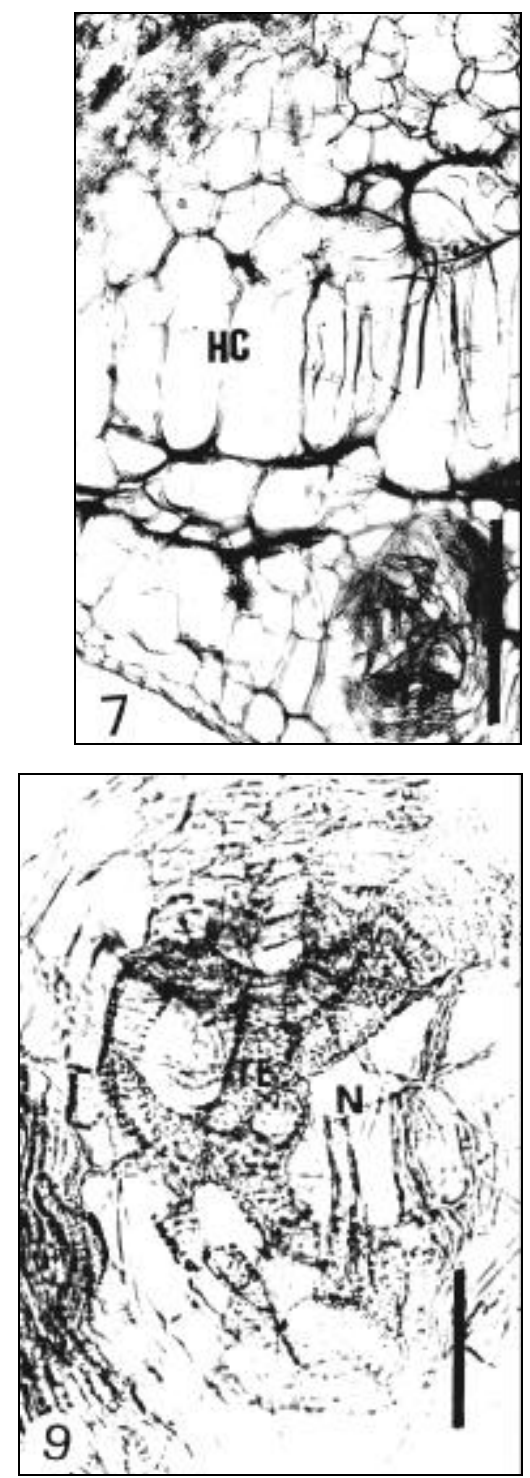

Figure 6. Transversal section of hypocotyl explant cultured in the presence of NAA $(2.7 \mu \mathrm{M})$ and KIN $(1.4 \mu \mathrm{M})$ during 100 days $(\mathrm{Bar}=200 \mu \mathrm{M})$. Figure 7. Detail of a region with parenchymatous and vasculartissue $(\mathrm{Bar}=200$ $\mu \mathrm{m})$. Figure 8. Transversal section of cotyledon cultured in the presence of NAA $(2.7 \mu \mathrm{M})$ and TDZ $(0.91 \mu \mathrm{M})$ for 60 days $(\mathrm{Bar}=200 \mu \mathrm{m})$. Figure 9. Detail of xylem nodule $(\mathrm{Bar}=50 \mu \mathrm{m})$. Legend: $(\mathrm{HC})$ hypertrophied cells, $(\mathrm{N})$ xylem nodule, (te) tracheary element. 

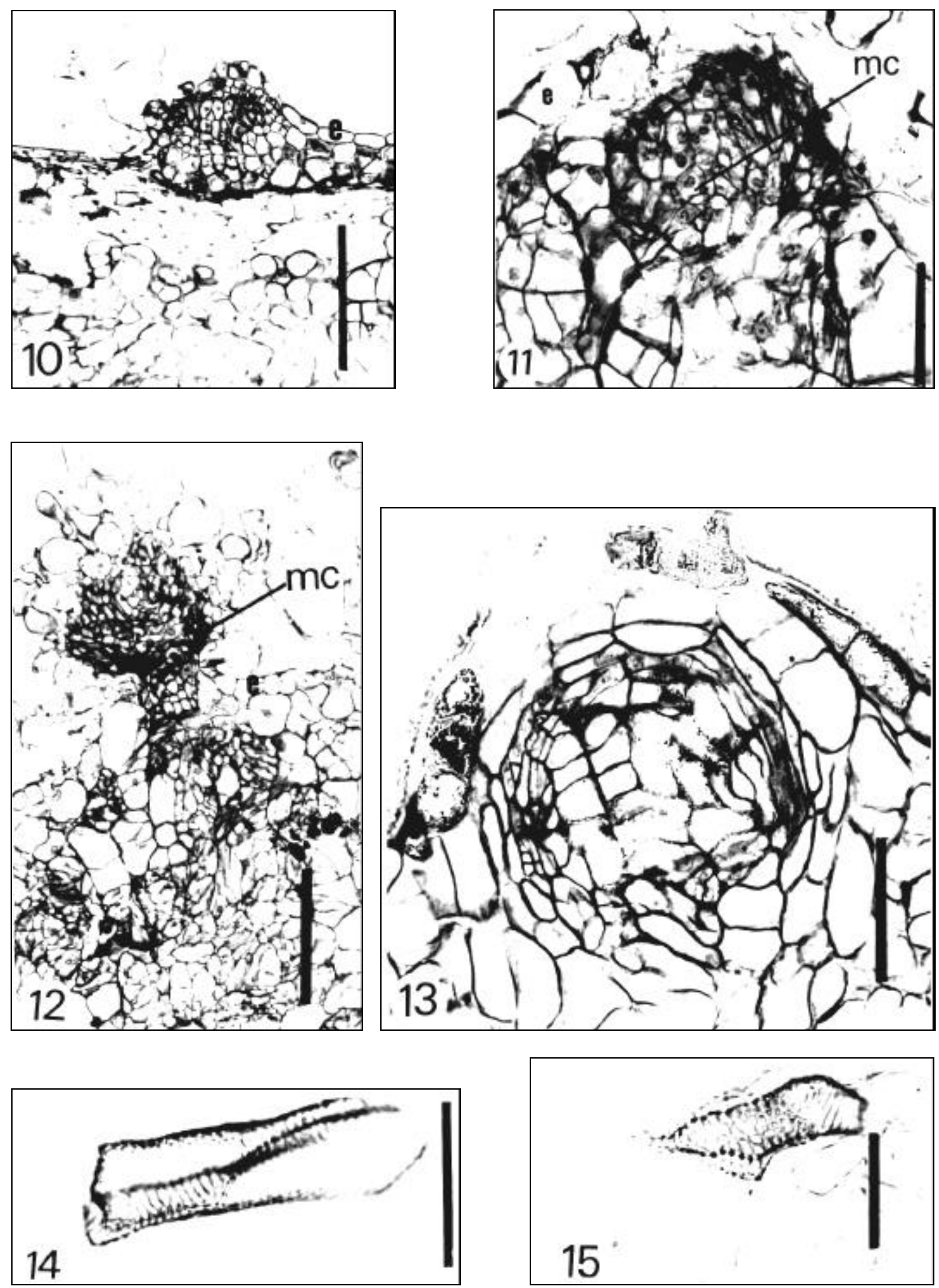

Figure 10. Longitudinal section of cotyledon explant cultured in the presence of NAA $(2.7 \mu \mathrm{M})$ and TDZ $(0.4 \mu \mathrm{M})$ during 90 days $(B a r=200 \mu \mathrm{m})$. Figures 11, 12 and 13. Longitudinal sections of cotyledon explant cultured in the presence of 2,4-D $(1.1 \mu \mathrm{M})$ and 4-CPPU $(8.1 \mu \mathrm{M})$ for 90 days showing meristematic cells (11and 12) (Bar $=50 \mu \mathrm{m}$ and $200 \mu \mathrm{m})$ and nodule $(13)(B a r=50 \mu \mathrm{m})$. Figures 14 and 15. Tracheids of cotyledon calli after 120 days on 2,4$\mathrm{D}(2.2 \mu \mathrm{M})$ and 4-CPPU $(8.1 \mu \mathrm{M})(\mathrm{Bar}=40 \mu \mathrm{m})$. Legend: $(\mathrm{mc})$ meristematic cells; (e) epidermis. 


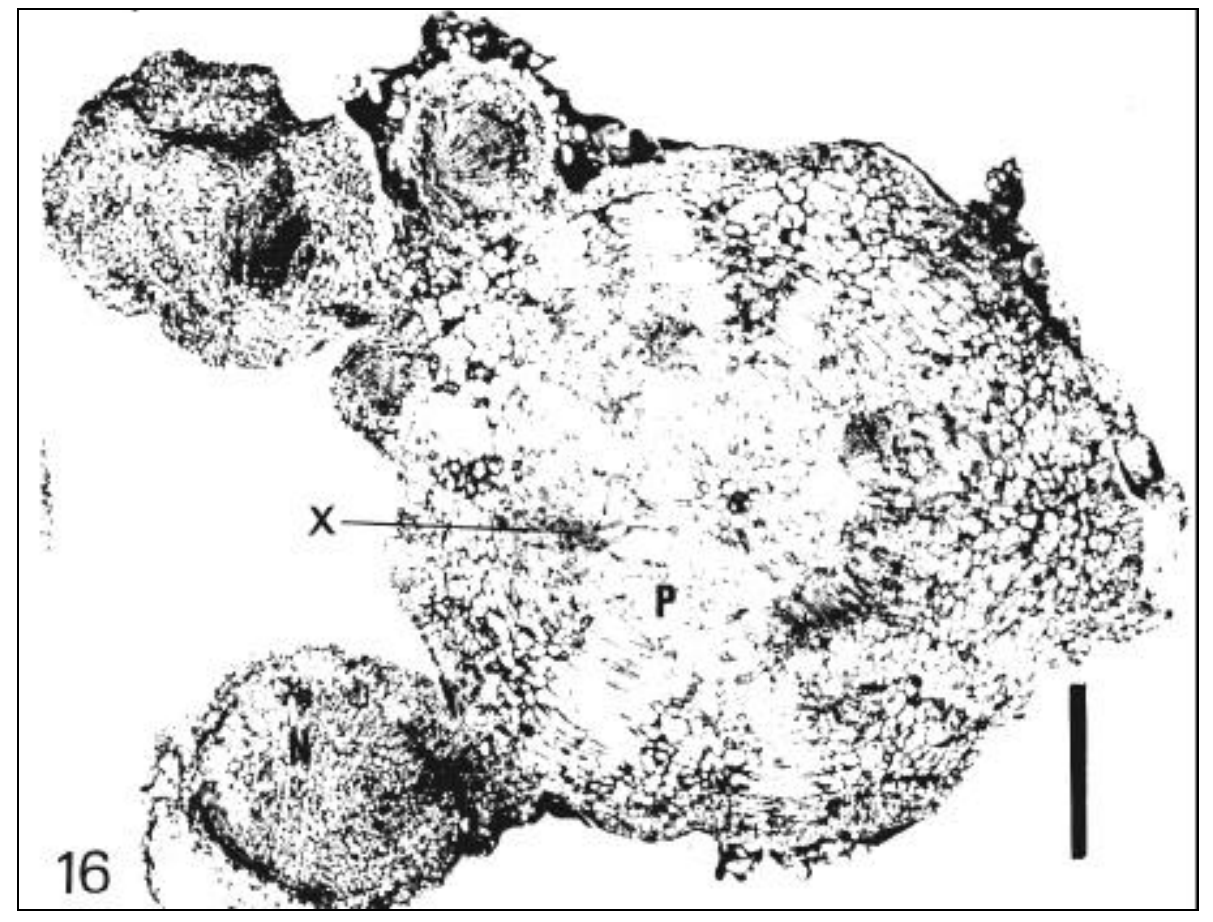

Figure 16. Hypocotyl section after 100 days on 4-CPPU $(20.2 \mu \mathrm{M})(\mathrm{Bar}=500 \mu \mathrm{m})$.

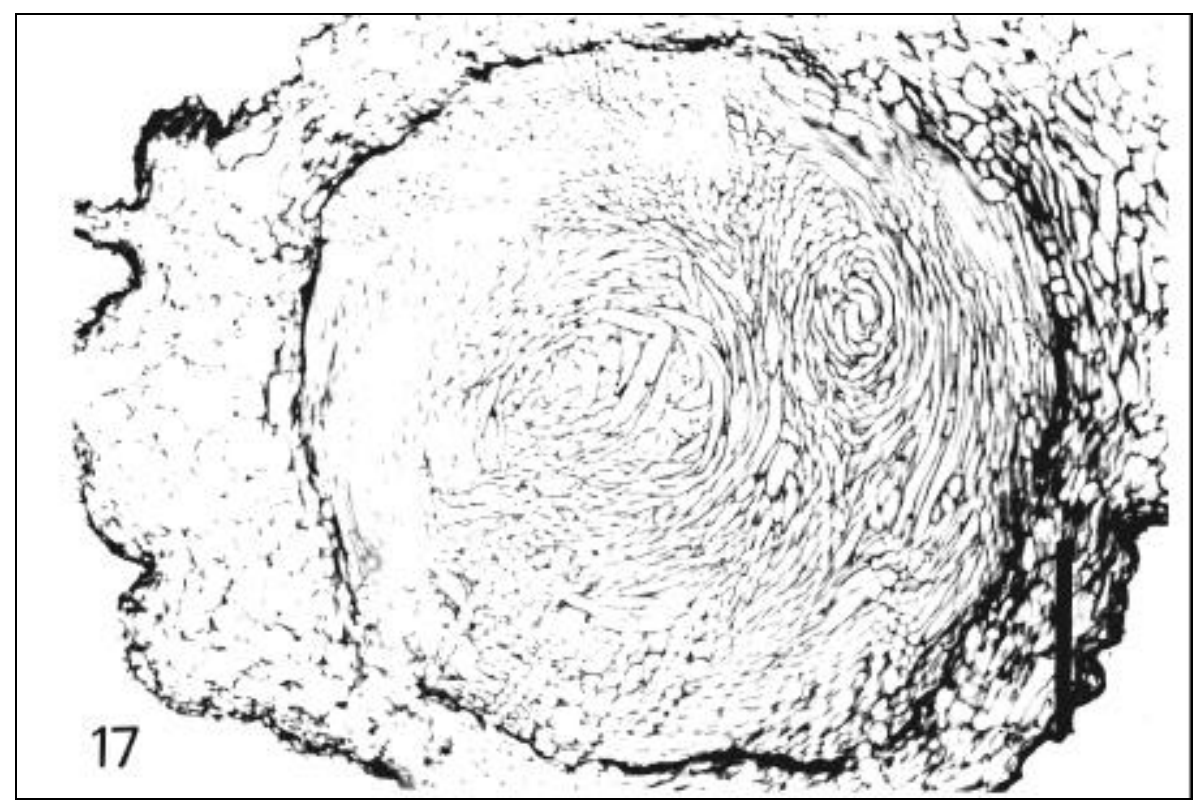

Figure 17. Circular nodule with xylem cells $(B a r=200 \mu \mathrm{m})$. Legend: $(\mathrm{N})$ nodule; $(\mathrm{X}) \mathrm{xylem} ;(\mathrm{P})$ parenchyma.

\section{DISCUSSION}

Differentiation rate of cotyledon and hypocotyl calli was low, as was described for the same species by Kitani and Yasutani (1997). These authors used a high concentration of cytokinin
(10 $\mu \mathrm{M}$ of KIN, zeatin, BA, 4-CPPU or TDZ) and a concentration of auxin $(2,4-\mathrm{D}$, NAA or 4Cl-IAA) equivalent to one tenth of cytokinin concentration. Like us, they observed some differentiation into buds in the presence of TDZ combined with an auxin. The growth regulators concentrations used in our work were different, 
except for 2,4-D and 4-CPPU (table 1). Our research on Acacia mearnsii organogenesis also showed low levels of differentiation for the same kind of tissues cultured in the presence of KIN or TDZ and NAA (Quoirin et al., 1998).

Hamzah et al. (1989) observed that a combination of indolacetic acid and kinetin initiated the development of callus from hypocotyls and radicles of $R$. mangium, but not from cotyledons, differently of our results with KIN and NAA combinations. In the presence of 2,4-dichlorophenoxyacetic acid and benzyladenine, multiple shoots were produced by cotyledons, but not by hypocotyls and radicles. In our case, meristems were formed in the presence of 2,4-D and 4-CPPU.

Rout et al. (1995), using the Woody Plant Medium (Lloyd and McCown, 1981) supplemented with $2.7 \mu \mathrm{M}$ of NAA and 13.9 $\mu \mathrm{M}$ of KIN, observed the formation of somatic embryos on callus from immature cotyledons of A. catechu. In our case, KIN concentrations were lower $(=9.3 \mu \mathrm{M})$ and no embryo was formed.

Histological studies of $R$. mangium calli 60 to 120 days after culture initiation showed hypertrophy of cortical and pith parenchyma cells. The same observation was made by Webb (1984) who described the hypertrophy of cortical cells situated below the epidermis in callus cultures of Diöon edule. In some cases, this proliferation caused the epidermal layer breakdown. However, Vieira (1997), working with Ipomoea batatas calli grown in the presence of IAA, reported the high volume of epidermic colenchymatous and parenchymatous cells, followed by intense cellular division in the cambial region of the caulinar explant. In $R$. mangium tissues cultured in vitro, cell divisions always occurred internally and externally, in contrast with Webb (1984) results. This author observed the formation of new periclinal walls in the external region of the callus, while internal divisions did not occur.

Vieira (1997) confirmed the important function of auxin during xylogenesis, describing the formation of traqueary elements from dedifferentiation of cortical parenchyma cells, as was observed in $R$. mangium hypocotyl. In case of cotyledon explants, dedifferentiation occurred in the cells of the chlorophyllous regular parenchyma.

Traqueary elements differentiating in the hypocotyl and cotyledon explants of $R$. mangium may have two origins: cambial cells division, or cortical parenchyma cells. In the first case, they are incorporated into the pre-existing xylem, in the second case, they remain isolated from the vascular bundles. Following Vieira (1997), traqueary elements isolated between parenchyma cells would not be functional, as there is no continuity with normal xylem.

Circular nodules with central xylem surrounded by parenchyma cells were described by Quoirin and Vieira (1995) in calli of Eucalyptus sp. They concluded that high concentrations of auxin and cytokinin seemed important for nodule formation. In the case of $R$. mangium, similar nodules were formed but it was not possible to determine if xylem surrounding cells were parenchymatous or phloem cells. On the other hand, Racosperma mangium presented the formation of traqueary elements with reticulated thickenings, while, in Eucalyptus calli, Quoirin and Vieira observed traqueary elements with annealed thickenings.

Quoirin and Vieira (1995) indicated that a meristemoid may be considered capable to respond to a stimulus, forming a radicular or caulinar meristem, or an embryoid, following the stimulus. Root meristems were observed in Eucalyptus sp. calli (Quoirin and Vieira, 1995) after 21 days on rooting medium, forming a cluster of meristematic cells, elongated toward the outside of the callus. In the treatment with $1.1 \mu \mathrm{M}$ of $2,4-\mathrm{D}$ and $8.1 \mu \mathrm{M}$ of 4-CPPU, $R$. mangium formed meristemoids without differentiation in organs. Many meristemoids originated a mass of cells which, following Gaspar (1995), could be called of cancer, as they did not differentiate traqueary elements nor assumed another function. The same author suggested that the incapacity to organize primary meristems could be considered as total lost of totipotency, as the tissues had no organogenic function any more and this state would be the terminal phase of neoplasic progression. 


\section{ACKNOWLEDGEMENTS}

We thank the European Economic Community for the financial support and CSIRO for providing the seeds. R. Marschner and N. K. Takemori received a grant of PIBIC Program (CNPq).

\section{RESUMO}

Várias combinações de reguladores do crescimento foram aplicadas a tecidos jovens de Racosperma mangium com o propósito de induzir a regeneração de brotos adventícios. Cinetina (KIN) e ácido naftalenoacético (NAA), tidiazuron (TDZ) e NAA, N-(chloro-4-piridil)$\mathrm{N}^{\prime}$-fenilurea (4-CPPU) e ácido 2,4diclorofenoxiacético (2,4-D) foram adicionados a um meio de base composto por sais minerais, na metade da concentração do meio MS, vitaminas MS e sacarose 2\%. Explantes de hipocótilos e cotilédones de plântulas semeadas in vitro foram cultivados nesses meios. A formação de calos foi observada em vários meios. Estruturas organizadas se desenvolveram na presença de diferentes combinações de KIN ou TDZ e NAA quando os calos permaneceram dois a três meses nos mesmos meios. Estudos histológicos mostraram a hypertrofia e hiperplasia das células do parênquima medular e cortical, nos calos formados a partir de hipocótilos como de cotilédones. A formação de células meristemáticas e de elementos traqueais foi observada durante a cultura in vitro. Em certos caso, nódulos de elementos traqueais apareceram. A maior diferenciação de células meristemáticas foi encontrada nos tecidos de cotilédones cultivados na presença de $8,07 \mu \mathrm{M}$ de 4-CPPU e 1,13 $\mu \mathrm{M}$ de 2,4-D.

\section{REFERENCES}

Berlyn, G.P. \& Miksche. J.P. (1976), Botanical microtechnique and cytochemistry. The Ames, Iowa State University Press, Iowa.

Brewbaker, J.L. (1989), Nitrogen fixing trees. In: Fast growing trees and nitrogen fixing trees, D.Werner \& P. Müller (Eds), Gustav
Fisher Verlag, Marburg, Germany, p. 253262.

Feder, N. \& O’Brien, T.P. (1968), Plant microtechnique: some principles and new methods. Amer. J. Bot., 33, 123-142.

Gaspar, T. (1995), The concept of cancer in in vitro plant cultures and the implication of habituation to hormones and hyperhydricity. Plant Tissue Cult. and Biotechn., 1, 126-136.

Hamzah, M.B., Alang, Z.C. \& Salekan, J. (1989), In vitro propagation of Acacia mangium from young seedlings. Tiss. Cult. For. Sp., 129-132.

Johansen, I. A (1940), Plant Microtechnique. McGraw-Hill Book Co Inc., New York.

Kitani, S. \& Yasutani, I. (1997), Callus cultures of Acacia species: initiation, growth optimisation and organogenesis. Proc. Inter. Workshop BIO-REFOR, IUFRO/SPDC, Brisbane, Australia.

Lloyd, G. \& McCown, B. (1981), Commercially feasible micropropagation of mountain laurel, Kalmia latifolia, by use of shoot-tip culture. Comb. Proc. Intl. Plant Prop. Soc., 30, 421-427.

Murashige, T. \& Skoog, F.(1962), A revised medium for rapid growth and bioassays with tobacco tissue cultures. Phys. Plant., 15, 473497.

National Research Council (1983), Mangium and other fast growing Acacias for the humid tropics. National Academic Press, Washington D.C. p.1-53.

O’Brien, T.P.; Feder, N. \& McCully, M.E. (1964), Polychromatic staining of plant cell walls by toluidine blue O. Protoplasma, 59, 368-373.

Quoirin, M., Bittencourt, J. V. M., Zanette, F. and Oliveira, D.E. de (1998), Effect of combinations of growth regulators on indirect in vitro organogenesis of Acacia mearnsii tissues. Rev. Bras. Fisiol. Veg., 10(2), 101105.

Quoirin, M. \& Vieira, R.C. (1995), Rhizogenesis and nodule formation from callus of Eucalyptus grandis and E. grandis $x$ urophylla. Arq. Biol. Tecnol., 38(3), 793-798.

Roeser, K.R. (1962). Die Nadel der Schwarzkiefer Massenprodukt und Kunstwerk der Natur. Mikrokosmos, Stuttgart, 61(2), 33-36.

Rout, G.R., Samantaray, S. \& Das, P. (1995), Somatic embryogenesis and plant 
regeneration from callus culture of Acacia catechu - a multipurpose leguminous tree. Plant Cell Tissue Organ Culture, 42, 283285.

Vieira, R.C. (1997), Diferenciação de xilema e floema em calos de Ipomoea batatas (L.) Lam. Tese (Doutor em Biotecnologia Vegetal) - Centro de Ciências da Saúde, Universidade Federal do Rio de Janeiro.
Webb, D.T. (1984), Developmental anatomy and histochemistry of light-induced callus formation by Diöon edule (Zamiaceae) seedling roots in vitro. Am. J. Bot., 71 (1), 65-68.
Received: February 15, 1999; Revised: March 18, 1999; Accepted: June 05, 1999. 